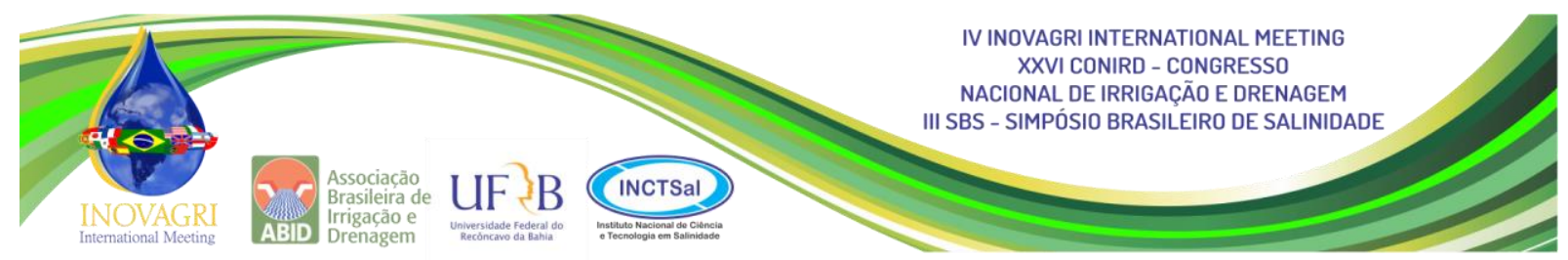

\title{
LYSIMETRIC EVALUATION OF SEBAL ALGORITHM IN SUBTROPICAL CLIMATE
}

\author{
W. Wolff ${ }^{1}$, M.V. Folegatti ${ }^{2}$, D. L. Flumignan ${ }^{3}$
}

\begin{abstract}
Understanding the spatio-temporal variation of evapotranspiration (ET) over irrigated agricultural areas is important to help the water management. Many remote sensing methods have been developed to estimate ET, among them the most used is the Surface Energy Balance Algorithm for Land (SEBAL). However, SEBAL was developed for particular sensors and regions, in which functions and empirical parameters inherent to its algorithm correspond to these regions and sensors. Therefore, the aim of this study was to evaluate the SEBAL algorithm for images of Landsat 8, through lysimetric data in a subtropical climate region. The study was carried out in two subtropical climate regions in Brazil. The first in the city of Piracicaba in the São Paulo state and the second in the city of Dourados in the Mato Grosso do Sul state. The images of Landsat 8 and the meteorological data are matching for the year 2013 to 2017 on a monthly scale for images and of 15 minutes for the meteorological data. Utilizing the SEBAL algorithm was estimated all the components of the energy balance and consequently the ET. Thus, the evaluation was done using goodness of fit measures to residuals. The results were reasonable; thus, the algorithm SEBAL can be used to the Landsat 8 images in subtropical climates, carefully. However, the calibration of the algorithm SEBAL must be performed to improve the estimates.
\end{abstract}

KEYWORDS: Evapotranspiration, remote sensing, goodness of fit.

\section{AVALIAÇÃO LISIMÉTRICA DO ALGORITMO SEBAL EM CLIMA SUBTROPICAL}

RESUMO: Compreender a variação espaço-temporal da evapotranspiração (ET) sobre as áreas agrícolas irrigadas é importante para ajudar na gestão da água. Muitos métodos de sensoriamento remoto foram desenvolvidos para estimar ET, entre eles o mais utilizado é o Surface Energy Balance Algorithm for Land (SEBAL). No entanto, o SEBAL foi desenvolvido para sensores e

\footnotetext{
${ }^{1}$ Postdoctoral researcher. ESALQ/USP, Piracicaba - São Paulo. Email; wwolff@ usp.br;

${ }^{2}$ Professor DSc. ESALQ/USP, Piracicaba - São Paulo;

${ }^{3}$ Researcher DSc. Embrapa, Dourados - Mato Grosso do Sul.
} 
regiões particulares, nos quais funções e parâmetros empíricos inerentes ao seu algoritmo correspondem a essas regiões e sensores. Portanto, o objetivo deste estudo foi avaliar o algoritmo SEBAL para imagens de Landsat 8, por meio de dados lisimétricos em clima subtropical. O estudo foi realizado em duas regiões do Brasil. A primeira na cidade de Piracicaba, no estado de São Paulo, e a segunda na cidade de Dourados, no estado do Mato Grosso do Sul. As imagens do Landsat 8 e os dados meteorológicos correspondem ao ano de 2013 a 2017 em uma escala mensal para as imagens e de 15 minutos para os dados meteorológicos. Utilizando o algoritmo SEBAL foram estimados todos os componentes do balanço de energia e, consequentemente, a ET. Dessa forma, a avaliação foi realizada por meio de medidas de ajuste de qualidade para os resíduos. Os resultados foram razoáveis; assim, o algoritmo SEBAL pode ser usado com cuidado para as imagens do Landsat 8 em climas subtropicais. No entanto, a calibração do algoritmo SEBAL deve ser realizada para melhorar as estimativas.

PALAVRAS-CHAVE: Evapotranspiração, sensoriamento remoto, qualidade de ajuste.

\section{INTRODUCTION}

Evapotranspiration (ET) is the amount of water transferred to the atmosphere through the plants evaporation (E) and transpiration (T) of the plants, thus it represents the crop hydric consumptions (ALLEN et al., 1998).

Different methods can be used to estimate or measure ET, for example, evaporimeter; lysimeter; Eddy covariance; Bowen ratio as well as by physic models as Penman-Monteith and Thornthwaite (BOWEN, 1926; SWINBANK, 1951; THORNTHWAITE; MATHER, 1955; ALLEN et al., 1998; PAUL et al., 2013). Weighing lysimeter is considered the method more precise (ALLEN et al., 2011b). However, this method and the others provide punctual estimates, based on information from meteorological stations.

Although these punctual estimates could be spatially interpolated, the knowledge under treatments and phases of the crops are necessary for an estimate more precise (AL ZAYED et al., 2016). However, these factors in large areas with crop diversity are more difficult to estimate (ALLEN et al., 2011a).

In this context, remote sensing (SR) data are useful to estimate ET and, consequently, in irrigation management (AL ZAYED et al., 2016). There are different methods based on SR to 
estimate ET, the most used and accepted is the Surface Energy Balance Algorithm for Land (SEBAL) (BASTIAANSSEN et al., 1998). Derived from the energy balance method, SEBAL has been used for several areas of irrigated agriculture in recent decades (BASTIAANSSEN, 2000). However, it has been calibrated and validated, mainly, for the sensors Thematic Mapper (TM) and Enhanced Thematic Mapper Plus (ETM+) from Landsat 5 and 7 satellites, respectively (BASTIAANSSEN et al., 2005; TEIXEIRA et al., 2009; ZHOU et al., 2014; AL ZAYED et al., 2016).

Currently, the Landsat program includes more modern sensors, the Operational Land Imager (OLI) and the Thermal Infrared Sensor (TIRS), onboard the Landsat 8 satellite (ROY et al., 2014).

Therefore, to evaluate the SEBAL algorithm for the OLI and TIRS sensors is important, allowing an evolution in the state of the art in this area of knowledge, especially for regions of subtropical climate, where irrigation is recurrent and the use of SEBAL allows a better management. The objective of this work was to evaluate the SEBAL algorithm for Landsat 8 images, in subtropical climate.

\section{MATHERIAL AND METHODS}

The work was performed in two regions (Figure 1). The first is located in the interior of São Paulo state, in Piracicaba city, and the second in the south of Mato Grosso do Sul state, in Dourados city. According to the climate, both cities are classified as subtropical humid (PEEL et al., 2007).

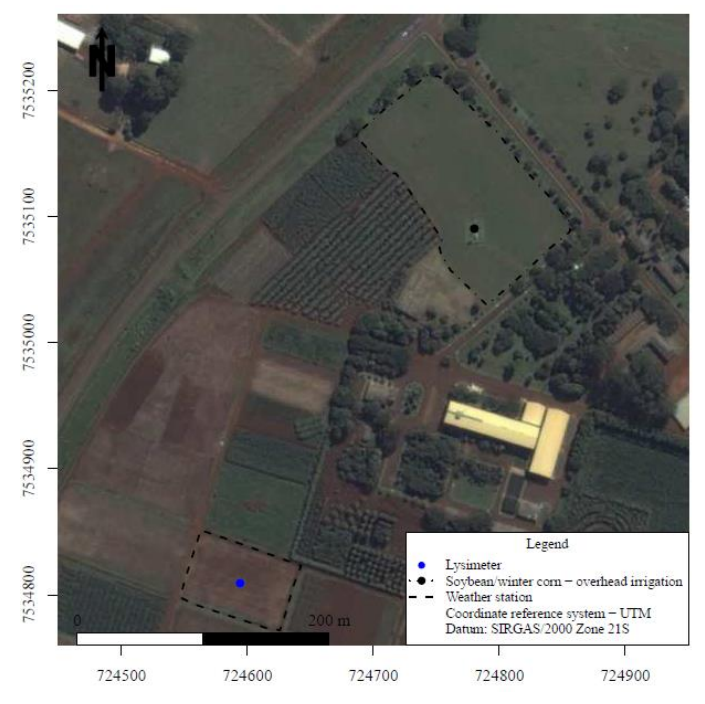



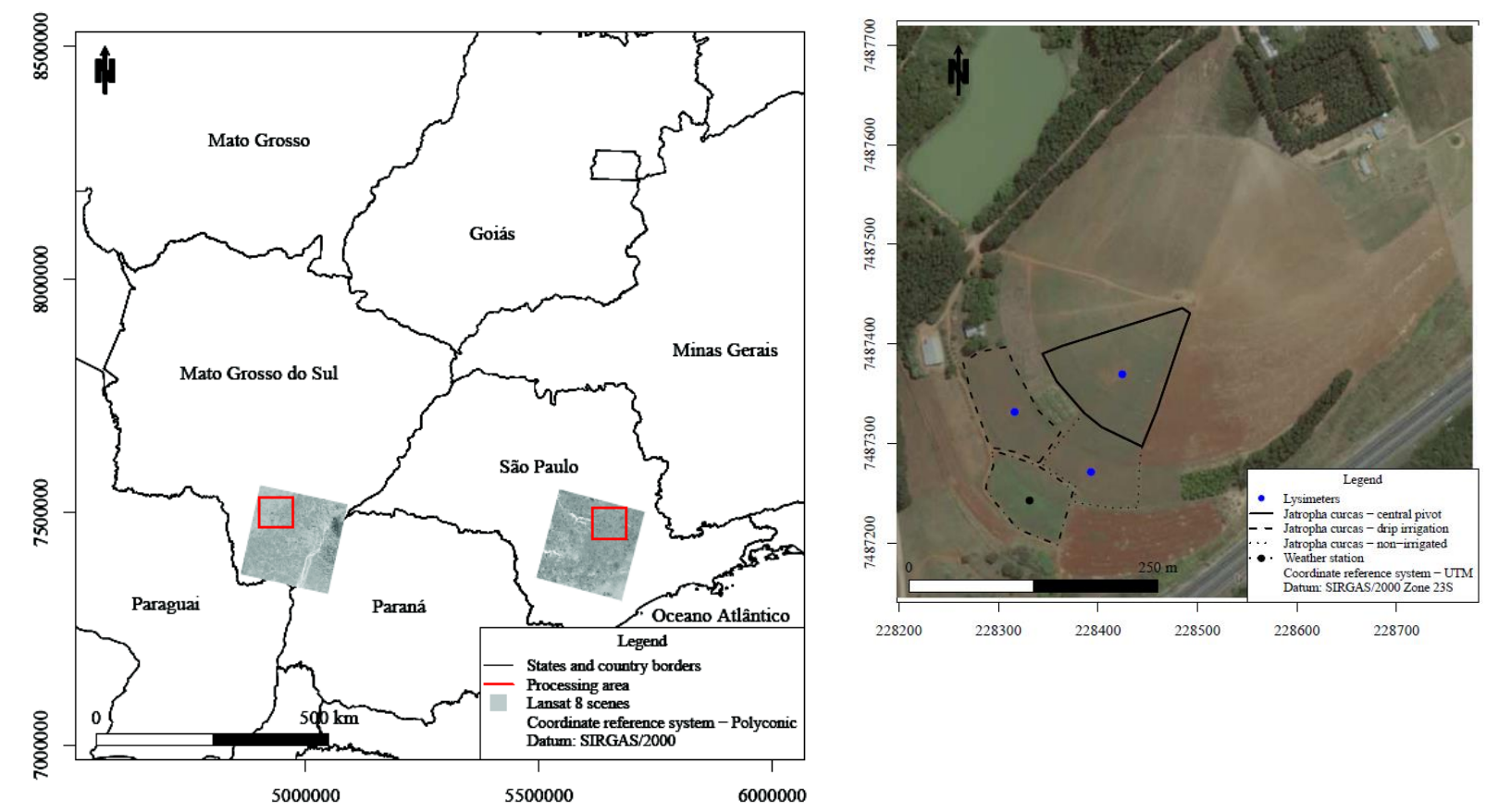

Figure 1. Work site. Top right - location of the lysimeters and weather station in Areão farm, ESALQ-USP. Bottom right - location of the lysimeter and weather station in Embrapa experimental farm. Fonte: Bing Aerial Maps

In addition to the location of work site, Figure 1 highlights processing area of the SEBAL algorithm. This area is far to $50 \mathrm{~km}$ from the weather station, this distance is a requirement to use the SEBAL algorithm (BASTIAANSSEN et al., 2005).

In Piracicaba city, the experimental area of Biosystems Engineering Department, located at Areão farm of "Luiz de Queiroz" College of Agriculture (ESALQ / USP) was used for calibration area. The projected coordinates are Longitude $228329.15 \mathrm{~m}$ and Latitude $7487242.25 \mathrm{~m}$. In all, three weighting lysimeters were used, located in areas cultivated by Jatropha, arranged in: 1 ha irrigated by central pivot, 0.5 ha irrigated by drip irrigation and 0.5 ha non-irrigated.

On the other hand, in Dourados city, the evaluation area was the experimental farm of Embrapa, located on the projected coordinates Longitude $724777.49 \mathrm{~m}$ and Latitude 7535090.03 $\mathrm{m}$ (Figure 1). One weighting lysimeter was used, located in a central area of the 0.55 ha, cultivated with alternate cropping between soybean and winter corn, irrigated by overhead irrigation.

According to the orbital data, images of the Landsat 8 and Terra satellites were used. These images were made available by the United States Geological Survey (USGS) at the website http://earthexplorer.usgs.gov/. 
The images obtained by Landsat 8 are derived from the OLI sensor, representing the spectral bands of the visible and infrared as well as TIRS sensor, representing the thermal bands (ROY et al., 2014). For the Terra satellite, a digital elevation model (DEM) was obtained by the sensor Advanced Spaceborne Thermal Emission and Reflection Radiometer, a product called Global Digital Elevation Model Version 2 (ASTER GDEM V2). The DEM is made available in spatial resolution of $30 \mathrm{~m}$.

All data were computed from 2014 and, thus, used in the SEBAL algorithm (BASTIAANSSEN et al., 2005).

At last, considering the measurements of the lysimeters as the standard value and the estimates by the SEBAL algorithm as observed value, the residual dispersion was studied, being evaluated some goodness of fit measures such as: mean error (ME), mean absolute error (AME), root mean square error (RMSE), and Nash-Suticliffe (NSE) efficiency coefficient (NASH; SUTCLIFFE, 1970). These goodness of fit measures were performed by the hydroGOF package (ZAMBRANO-BIGIARINI, 2014) of R Statistical 3.3.0® software; (R Core Team, 2016).

\section{RESULTS AND DISCUSSION}

Table 1 highlights the standard values, obtained by the lysimeters and the observed values, obtained by the SEBAL algorithm. For the lysimeters with Jatopra, located in Piracicaba city and operated on central pivot, drip irrigation, and non-irrigated treatments was observed a greater error than the lysimeter located in Dourados city. As Jatopra is a perennial crop, when the canopy openness is maximum the evapotranspiration estimates by the SEBAL algorithm can be influenced by the soil evaporation. However, when the canopy is closed we observed a suitable performance.

For the lysimeter in Dourados city under sprinkler irrigation method, the performance of the SEBAL algorithm was excellent, once the crop cultivated on area is continuous without canopy openness. 
W. Wolff et al.

Table 1. Evapotranspiration evaluation.

\begin{tabular}{|c|c|c|c|}
\hline Date & Irrigation system & ET lysimeter $(\mathrm{mm})$ & ET SEBAL $(\mathrm{mm})$ \\
\hline $09-11-14$ & Pivot & 1.12 & 3.03 \\
\hline $09-11-14$ & Drip & 1.45 & 3.62 \\
\hline $09-11-14$ & Non-irrigated & 2.04 & 2.18 \\
\hline $10-13-14$ & Pivot & 3.12 & 2.70 \\
\hline $10-13-14$ & Drip & 3.00 & 3.42 \\
\hline $10-13-14$ & Non-irrigated & 1.51 & 1.60 \\
\hline $10-29-14$ & Pivot & 4.10 & 4.31 \\
\hline $10-29-14$ & Drip & 2.31 & 4.18 \\
\hline $10-29-14$ & Non-irrigated & 1.86 & 3.27 \\
\hline $12-16-14$ & Pivot & 7.66 & 7.82 \\
\hline $12-16-14$ & Drip & 6.13 & 6.72 \\
\hline $12-16-14$ & Non-irrigated & 5.74 & 6.59 \\
\hline $03-18-15$ & Sprinkler & 2.28 & 2.12 \\
\hline $05-05-15$ & Sprinkler & 3.63 & 3.21 \\
\hline 05-09-15 & Pivot & 1.30 & 1.56 \\
\hline $05-09-15$ & Drip & 1.34 & 1.94 \\
\hline $05-09-15$ & Non-irrigated & 1.37 & 1.40 \\
\hline $06-06-15$ & Sprinkler & 3.79 & 3.51 \\
\hline $06-10-15$ & Pivot & 2.08 & 2.53 \\
\hline $06-10-15$ & Drip & 2.79 & 2.65 \\
\hline $06-10-15$ & Non-irrigated & 2.19 & 2.30 \\
\hline $06-22-15$ & Sprinkler & 2.44 & 2.72 \\
\hline $06-26-15$ & Pivot & 0.99 & 1.89 \\
\hline $06-26-15$ & Drip & 1.04 & 2.35 \\
\hline $06-26-15$ & Non-irrigated & 0.71 & 1.22 \\
\hline
\end{tabular}

According to the goodness of fit measures, the mean error was 0.51, the mean absolute error was 0.63 , the root mean square error was 0.88 , and Nash-Suticliffe (NSE) efficiency coefficient was 0.74 . These goodness of fit measures highlight the SEBAL algorithm overestimates slightly the evapotranspiration. Therefore, using Landsat 8 images, the evapotranspiration can be estimated parsimoniously in subtropical climates. The Figure 2 shows the evapotranspiration spatial pattern. 

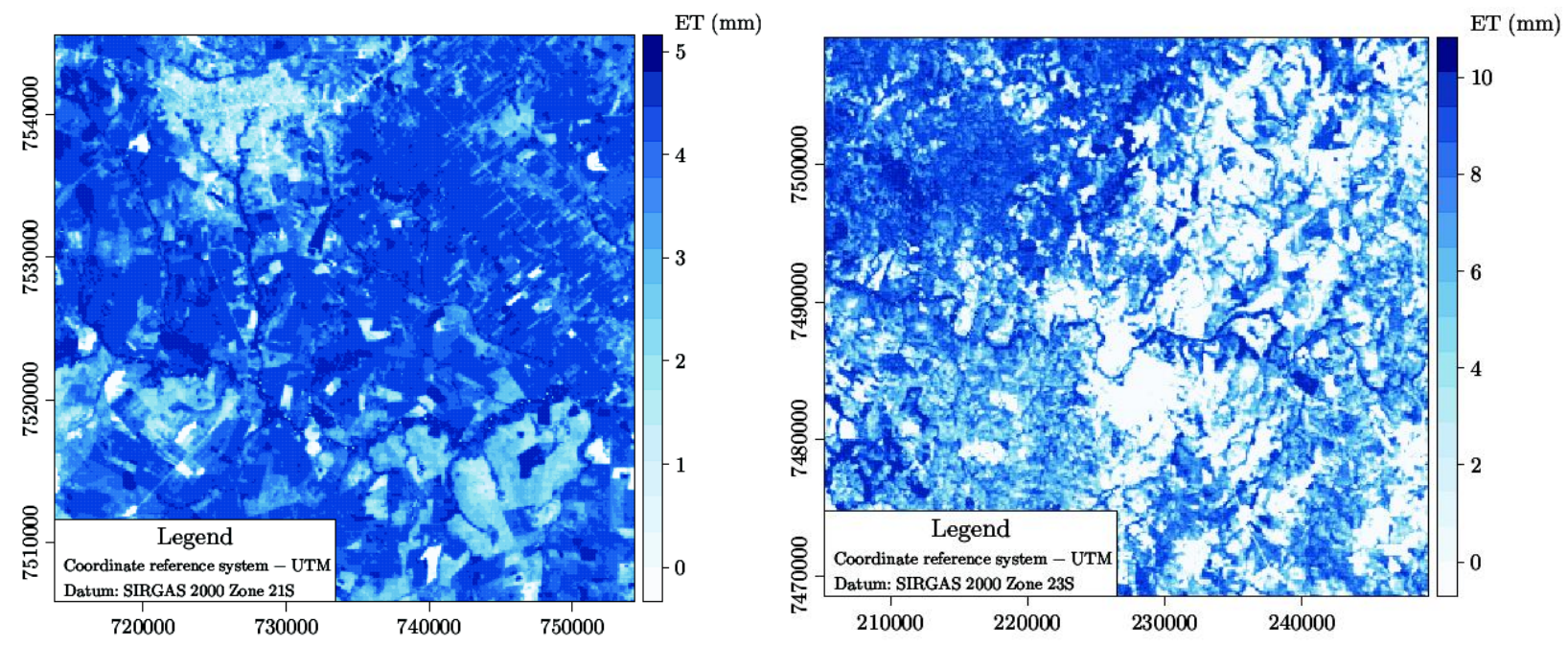

Figure 2. Evapotranspiration mapping. Left - Dourados city on 05/05/2015. Right - Piracicaba city on 12/16/2014

\section{CONCLUSION}

SEBAL algorithm can be used for Landsat 8 images in regions of subtropical climate. Although their evapotranspiration estimations have been slightly overestimated was observed a suitable performance.

\section{REFERÊNCIAS}

ALLEN, R.; IRMAK, A.; TREZZA, R.; HENDRICKX, J. M. H.; BASTIAANSSEN, W.; KJAERSGAARD, J. Satellite-based ET estimation in agriculture using SEBAL and METRIC. Hydrological Processes, v. 25, n. 26, p. 4011-4027, 2011. Available at: http://doi.wiley.com/10.1002/hyp.8408.

ALLEN, R. G.; PEREIRA, L. S.; HOWELL, T. A.; JENSEN, M. E. Evapotranspiration information reporting: I. Factors governing measurement accuracy. Agricultural Water Management, Elsevier B.V., v. 98, n. 6, p. 899-920, 2011. Available at: http://dx.doi.org/10.1016/j.agwat.2010.12.015.

ALLEN, R. G.; PEREIRA, L. S.; RAES, D.; SMITH, M. Crop evapotranspiration - Guidelines for computing crop water requirements. Rome, 1998. (FAO Irrigation and drainage paper, 56). Available at: http://www.fao.org/docrep/X0490E/X0490E00.htm. 
ALLEN, R. G.; TASUMI, M.; TREZZA, R. Satellite-Based Energy Balance for Mapping Evapotranspiration with Internalized Calibration (METRIC)-Model. Journal of Irrigation and Drainage Engineering, v. 133, n. 4, p. 380-394, 2007. Available at: http://ascelibrary.org/doi/abs/10.1061/(ASCE)0733-_9437(2007)133\\%3A4(380).

AL ZAYED, I. S.; ELAGIB, N. A.; RIBBE, L.; HEINRICH, J. Satellite-based evapotranspiration over Gezira Irrigation Scheme, Sudan: A comparative study. Agricultural Water Management, Elsevier B.V., v. 177, p. 66-76, 2016. Available at: http://linkinghub.elsevier.com/retrieve/pii/S0378377416302323.

BASTIAANSSEN, W. SEBAL-based sensible and latent heat fluxes in the irrigated Gediz Basin, Turkey. Journal of Hydrology, v. 229, n. 1-2, p. 87-100, 2000. Available at: http://linkinghub.elsevier.com/retrieve/pii/S0022169499002024.

BASTIAANSSEN, W. G. M.; MENENTI, M.; FEDDES, R. A.; HOLTSLAG, A. A. M. A remote sensing surface energy balance algorithm for land (SEBAL). 1. Formulation. Journal of Hydrology, v. 212-213, n. 1-4, p. 198-212, 1998. Available at: http://linkinghub.elsevier.com/retrieve/pii/S0022169498002534.

BASTIAANSSEN, W. G. M.; NOORDMAN, E. J. M.; PELGRUM, H.; DAVIDS, G.; THORESON, B. P.; ALLEN, R. SEBAL Model with Remotely Sensed Data to Improve WaterResources Management under Actual Field Conditions. Journal of Irrigation and Drainage Engineering, $\quad$ v. 131, p. 85-93, $2005 . \quad$ Available at: http://ascelibrary.org/doi/10.1061/(ASCE)0733-_9437(2005)131:1(85).

BOLTZMANN, L. Ableitung des Stefan'schen Gesetzes, betreffend die Abhängigkeit der Wärmestrahlung von der Temperatur aus der electromagnetischen Lichttheorie. Annalen der Physik, v. 258, n. 6, p. 291-294, 1884. Available at: http://doi.wiley.com/10.1002/andp.18842580616.

BOWEN, I. S. The Ratio of Heat Losses by Conduction and by Evaporation from any Water Surface. Physical Review, v. 27, n. 6, p. 779-787, 1926. Available at: http://link.aps.org/doi/10.1103/PhysRev.27.779. 
Food and Agriculture Organization of the United Nations (FAO). AQUASTAT website. 2016. Available at: http://www.fao.org/nr/water/aquastat/water`use/index.stm. Accessed on: 05 jul.2016.

GRASS Development Team. Geographic Resources Analysis Support System (GRASS GIS) Software, Version 7.0. 2016. Available at: http://grass.osgeo.org.

NASH, J. E.; SUTCLIFFE, J. V. River flow forecasting through conceptual models part I - A discussion of principles. Journal of Hydrology, v. 10, n. 3, p. 282-290, 1970. Available at: http://linkinghub.elsevier.com/retrieve/pii/0022169470902556.

PAUL, G.; GOWDA, P. H.; VARA PRASAD, P. V.; HOWELL, T. A.; STAGGENBORG, S. A.; NEALE, C. M. U. Lysimetric evaluation of SEBAL using high resolution airborne imagery from BEAREX08. Advances in Water Resources, Elsevier Ltd, v. 59, p. 157-168, 2013. Available at: http://dx.doi.org/10.1016/j.advwatres.2013.06.003.

PEEL, M. C.; FINLAYSON, B. L.; MCMAHON, T. A. Updated world map of the Köppen-Geiger climate classification. Hydrology and Earth System Sciences, v. 11, n. 5, p. 1633-1644, 2007. Available at: http://www.hydrol-_earth-_syst-_sci.net/11/1633/2007/.

R Core Team. R: A Language and Environment for Statistical Computing, Version 3.3.0. 2016. Available at: http://www.R-_project.org/.

ROY, D. P.; WULDER, M. A.; LOVELAND, T. R.; C.E., W.; ALLEN, R. G.; ANDERSON, M. C.; HELDER, D.; IRONS, J. R.; JOHNSON, D. M.; KENNEDY, R.; SCAMBOS, T. A.; SCHAAF, C. B.; SCHOTT, J. R.; SHENG, Y.; VERMOTE, E. F.; BELWARD, A. S.; BINDSCHADLER, R.; COHEN, W. B.; GAO, F.; HIPPLE, J. D.; HOSTERT, P.; HUNTINGTON, J.; JUSTICE, C. O.; KILIC, A.; KOVALSKYY, V.; LEE, Z. P.; LYMBURNER, L.; MASEK, J. G.; MCCORKEL, J.; SHUAI, Y.; TREZZA, R.; VOGELMANN, J.; WYNNE, R. H.; ZHU, Z. Landsat-8: Science and product vision for terrestrial global change research. Remote Sensing of Environment, Elsevier B.V., v. 145, p. 154-172, 2014. Available at: http://dx.doi.org/10.1016/j.rse.2014.02.001.

SWINBANK, W. C. The measurement of vertical transfer of heat and water vapor by eddies in the lower atmosphere. Journal of Meteorology, v. 8, n. 3, p. 135-145, 1951. Available at: http://dx.doi.org/10.1175/1520-_0469(1951)008<_0135:TMOVTO>_2.0.CO;2. 
TEIXEIRA, A. H. C.; BASTIAANSSEN, W. G. M.; AHMAD, M. D.; BOS, M. G. Reviewing SEBAL input parameters for assessing evapotranspiration and water productivity for the LowMiddle São Francisco River basin, Brazil. Agricultural and Forest Meteorology, v. 149, n. 3-4, p. 477-490, 2009. Available at: http://linkinghub.elsevier.com/retrieve/pii/S0168192308002578.

THORNTHWAITE, C. W.; MATHER, J. R. The Water Balance. Drexel Institute of Technology, Laboratory of Technology, 1955. (Publications in climatology). Available at: https://books.google.co.in/books?id=DTdtcgAACAAJ.

ZAMBRANO-BIGIARINI, M. hydroGOF: Goodness-of-fit functions for comparison of simulated and observed hydrological time series. 2014. R package version 0.3-8. Available at: https://CRAN.R-_project.org/package=hydroGOF.

ZHOU, X.; BI, S.; YANG, Y.; TIAN, F.; REN, D. Comparison of ET estimations by the threetemperature model, SEBAL model and eddy covariance observations. Journal of Hydrology, Elsevier B.V., v. 519, n. PA, p. 769-776, 2014. Available at: http://dx.doi.org/10.1016/j.jhydrol.2014.08.004. 